\title{
INVESTMENTS IN HUMAN CAPITAL DEVELOPMENT AND WAGES: RELATIONSHIPS AND PROBLEMS IN LOWER-MIDDLE-INCOME COUNTRIES
}

\author{
Myroslava Olievska' ${ }^{\text {, Arthur Romanov }}{ }^{2}$
}

\begin{abstract}
The purposes of the article are to assess the impact of financing of education and health to human capital development, to consider the relationship among wages and investment in human capital, to establish directions of improvement of the investments in human capital development in Ukraine and other lower-middle-income countries. Methodology. Methodological basis of the research is the study of the dynamics of such indicators as the Human Capital Index 2020, wages, GNI per capita, education expenditure, government expenditure, financing of health, the wages of full-time employees. To solve the problems arising from the purpose of the study, systemic method (when analyzing the relationship of the investments in human capital development and wages), statistical methods of comparisons, economic analysis (when processing statistics), historical method (in the study of the evolution of Human Capital Index, expenditures on health and education), empirical and correlation-regression analysis (in the analysis of the practice of investments in human capital development) have been used. Results. The human capital is a central driver of sustainable growth and poverty reduction. The article proves that high-income countries can better finance the development of human capital; they are the leaders of the Ukraine Index 2020, more human capital in high-income countries is associated with higher earnings for people, higher income for countries, and stronger cohesion in societies. At the same time, the article substantiates that the low level of GNI per capita (3370 USD in Ukraine) and insufficient level of education and health expenditure negatively affect formation of human capital (the 53rd place in the Human Capital Index 2020). On the basis of the study of government and non-government expenditure on education and health, it has been concluded that investments in human capital are the effective tool to increase of the wages of full-time employees. Practical implications. Today human capital gains in many countries are at risk, especially in lower-middle-income countries. Features of the current socioeconomic situation require strengthening of investments in human capital development. The main steps that are necessary to undertake for implementing changes in the investments in human capital development have been determined in the article. They are the following: optimization of state financing of human capital; creation of fiscal space; creation of regional funds for financing human capital development; creation of strategic alliances and partnerships; supporting the demand for education and health care from households. Value/originality. The relationships between investments in human capital development and wages in the lower-middle-income countries are analytically proved. The complex of actions on optimization of financing of human capital has been generalized.
\end{abstract}

Key words: human capital, investments in human capital development, wages, lower-middle-income countries, expenditure on education, expenditure on health, public expenditure on education, public expenditure on health.

JEL Classification: J24, I15, I18, I22, I25, Q01

\section{Introduction}

Human capital is the key to overcoming poverty and hunger, ensuring decent work and economic growth, reducing inequality, and achieving gender equality. After all, knowledge, skills, and abilities, as well as health and other human capital assets, can influence the income of both human capital carriers and bring benefits to its consumers through development and financing. For decades, international organizations, scholars, and experts have been trying to explain the relationship

\footnotetext{
Corresponding author:

${ }^{1}$ Military Institute of Taras Shevchenko National University of Kyiv, Ukraine.

E-mail:3mad@ukr.net

ORCID: https://orcid.org/0000-0001-8818-0509

${ }^{2}$ Academician Stepan Demianchuk International University of Economics and Humanities, Ukraine.

E-mail: romanovad@ukr.net

ORCID: https://orcid.org/0000-0002-5825-4738
} 
between investment in human capital development, economic (wages, profits, gross national income), and non-economic benefits.

The emerging interest of the world community in the human capital can also be justified by the fact that the needs of all economic actors are constantly growing, the nature of work is changing, new challenges are arising (including the potential impact of the COVID-19 pandemic on human capital development and the economy as a whole (COVID-19 and Human Capital, 2020)), and threats to achieving the Global Sustainable Development Goals (Transforming our world: the 2030 Agenda for Sustainable Development, 2015), as a result, the role of investment in the development of human capital is growing.

Increased attention to the development of human capital and its financing is clearly confirmed by the World Bank study. Firstly, the experts divided the world economies into four groups: low-income countries, lower-middle-income countries, upper-middleincome countries, and high-income countries (New World Bank country classifications by income level, 2020); secondly, they conducted significant analytical work on the use of human capital and calculated The Human Capital Index 2020 based on the latest data on health and education (The Human Capital Index 2020 Update, 2020). A comparison of these studies suggests that the leaders of The Human Capital Index 2020 are high-income countries (Singapore, Hong Kong, Japan, the Republic of Korea, Canada, China, Finland, Sweden, Ireland, the Netherlands), outsiders are low-income countries (Liberia, Mali, Niger, South Sudan, Chad, the Central African Republic). Ukraine is ranked 53rd in terms of human capital development and has a score of 0.63 , which is typical for most other lower-middle-income countries. This level of human capital development in Ukraine may indicate significant shortcomings in human capital financing (lack of financial resources, inefficient use of mobilized resources, lack of motivational component), which encourages research on human capital financing trends in Ukraine and the relationship between human capital costs and wages as an economic benefit from the use of human capital.

\section{Brief literature review}

Awareness of the important role of human capital has led to a significant increase in the interest of scientists in studying the impact of education and experience on wages. At one time, A. Smith noted that wages should cover the costs associated with training and acquiring additional skills. Later, J. Mincer proved that vocational training affected the individual distribution of income among the population, analyzing the distribution of earnings depending on the distribution of knowledge and skills; in essence, this was the first attempt to create a theory of human capital (Mincer, 1958). G. Becker argued that rational subjects would invest in human capital development only if the expected flow of future benefits exceeded the short-term costs associated with the acquisition of knowledge and skills, and even derived the trajectory of lifelong earnings (Becker, 1993). Christian Dustmann, Costas Meghir called benefits in the form of wages the main indicator of the level of education, knowledge, and skills of human capital; accordingly, the source of wage growth was the development of general, unique, and specific human capital (Christian Dustmann, 2005). Herrendorf, Berthold, and Todd Schoellman used a structural approach to explain different levels of human capital development and labor incomes in agriculture and other sectors of the economy (Herrendorf, Berthold, and Todd Schoellman, 2018).

We share the views of scholars who argue that the propensity of human capitalists to invest in education and the human capital they have accumulated depend on the expected benefits in the form of wages; such studies provide a deeper understanding of the processes of human capital development, its role in shaping family incomes and economic inequality.

However, in our opinion, the question of how investments in human capital affect income growth and poverty reduction in countries with different levels of economic development is insufficiently studied. In particular, the relationship between the costs of human capital development and wages is poorly studied in lower-middle income countries (for example, in Ukraine), which determines the relevance and purpose of the study.

\section{Purpose of the paper}

Based on the above, we consider it appropriate to determine the relationship between the level of human capital and wages in lower-middle income countries. Accordingly, the purpose of the article is to assess the impact of education and health care financing on human capital development; to study the relationship between investment in human capital and wages, which will serve as a basis for substantiation of proposals for optimizing investment in human capital development in Ukraine and other lower-middle-income countries.

\section{Financing of human capital development in Ukraine: trends and problems}

Given that human capital is a central driver of sustainable growth and poverty reduction, the priority of Ukraine's national interests and national security is, among other things, social development and, above all, human capital development through modernization of education and science, health, culture, and social protection (Pro Stratehiiu natsionalnoi bezpeky 
Ukrainy, 2020). In our opinion, it is important to identify measures to reform the education system and bring educational standards to the needs of social development and to the best world standards, to create jobs, to ensure people's rights to health care, in particular, the promotion of a healthy lifestyle, to eliminate all inequalities and discrimination, but those steps are insufficient for the development and accumulation of human capital in Ukraine, as evidenced by the World Bank. In particular, according to the level of GNI per capita, Ukraine is among the lower-middle-income countries (New World Bank country classifications by income level, 2020).

According to the Human Capital Index 2020 (HCI), a child born in 2020 in Ukraine will be only 63\% as productive as he or she can be in the future due to a number of educational and health restrictions (while in countries with a high level of income, this figure is about $80-82 \%$, and the average for all countries is $56 \%)$. In addition, a child who starts school at the age of 4 can expect to finish 12.9 years of study before the age of 18; Ukrainian students score 478 points, while 625 points mean advanced and 300 points are minimum achievements; the expected duration of training is only 9.9 years, taking into account the level of training; in Ukraine, HCI for girls is higher than for boys 0.68 and 0.59 , respectively. In Ukraine, 28\% (2007) of 10 -year-olds cannot read and understand a simple text until the end of primary school, which indicates poor quality education and a significant lag behind European countries in this indicator $(11 \%)$. The coverage ratio for preschool education is $84 \%$ (2013), it is $85 \%$ in European countries; in countries with incomes below the average $-49 \%$; $56 \%$ of adults aged $30-34$ have higher education.

Most health indicators are worse than in other countries. In particular, in Ukraine, the probability of death from cardiovascular disease, cancer, diabetes, or chronic respiratory diseases between the ages of 30 and 70 significantly exceeds that of other countries and is $25 \%$ (2016). In addition, 32\% (2015) of the population over the age of 18 have hypertension; $6 \%$ (2019) of the population aged 20-79 suffer from type 1 or 2 diabetes. The Universal Health Coverage index in Ukraine is 68 (2017), while it is 75 in European countries; it is 56 in lower-middle-income countries (Insights from Disaggregating the Human Capital Index, 2020).

Regarding the financing of education and health care, public expenditure on health care is $3.1 \%$ of GDP (2017), which is below average in Europe and Central Asia (4.9\%), but above average for lower-middleincome-countries (2.8\%); public expenditure on education $-5.4 \%$ of GDP (2017), which exceeds both averages in Europe and Central Asia (4.6\%) and lowermiddle-income countries (4.5\%).

Thus, the obvious achievements of human capital accumulation in Ukraine are the indicators of coverage of preschool education, the level of adult education. However, wages and human capital utilization are low. For example, $65 \%$ of the economically active population is employed in European countries; in lower-middle-income countries, this level reaches $54 \%$; in Ukraine, it is 58\% (2013) (Insights from Disaggregating the Human Capital Index, 2020). Comparison of achievements and expenditures on education and health care may indicate inefficient use of taxpayers' funds, low level of participation of the corporate sector in human capital development, etc. That is why we consider it appropriate to dwell on the study of the relationship between the costs of human capital development (expenditures on education and health care at the expense of state and local budgets; funds of the legal entities and individuals, NGOs, and foundations) and Ukraine's position in the Human Capital Index ranking.

It should be noted at once that the rating value of Ukraine in the World Bank study did not change significantly and was 0.63 in 2010, 0.65 in 2017 and 0.64 in 2018, 0.63 in 2020 (The Human Capital Index

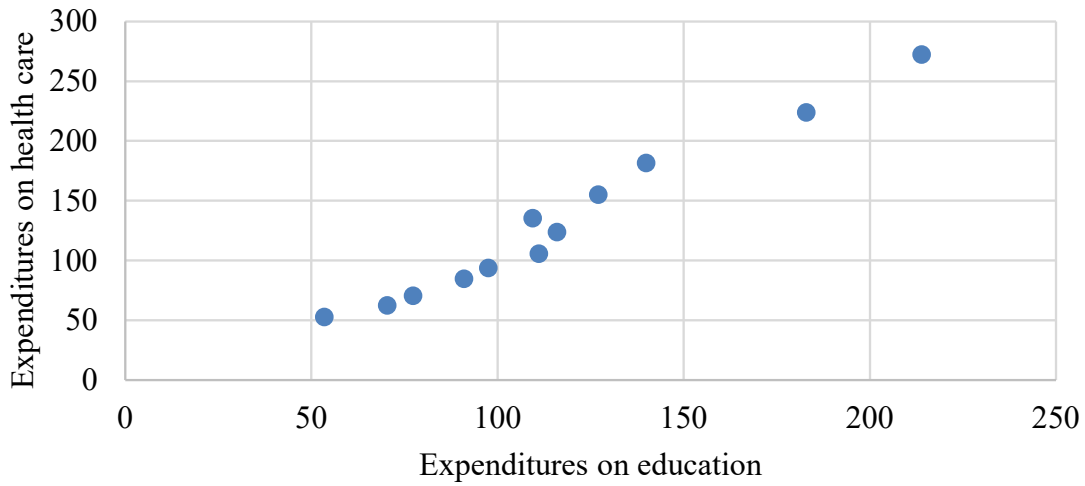

Figure 1. Distribution of expenditures on education and health care in Ukraine in 2007-2018

Source: based on (Derzhavna sluzhba statystyky Ukrainy, 2020) 
2020 Update, 2020), at the same time, there were directly proportional changes in funding for education and health care (Figure 1).

In the financing of education, the share of public expenditure is dominant, it is increasing annually and amounting to $88.5 \%$ in 2018 ; in the structure of health care expenditure, public and private expenditure have approximately the same share with a variable slight dominance. At the same time, more than $95 \%$ of nongovernment expenditure are made by households. Correlation analysis between the value of HCI and the amount of funding for education and health care in Ukraine has shown that public expenditure on education is more related to the formation of human capital than private expenditure (Table 1). The correlation coefficient of public expenditure on education and HCI is 0.7262 , coefficient of private expenditure is 0.5974 , and health care expenditure are 0.7144 and 0.7103 , respectively.

Due to additional research on the structure of education expenditure by funding organizations and educational functions, it has been found and analytically proved that:

1) private firms and corporations are almost not involved in financing education in Ukraine; business share in financing education services is less than $1 \%$ ( $0.97 \%$ in 2010 and $0.67 \%$ in 2018 );
2 ) there is a strong inverse correlation between $\mathrm{HCI}$ and expenditure of households on other educational services (food, administrative services, inventory, textbooks); therefore, it is advisable to increase the share of the state in financing education.

Correlation and regression analysis of education funding by educational level and the number of students has shown the presence of correlation of the number of students enrolled in vocational and higher education to the corresponding funding. However, statistically significant dependencies in these cases are also not observed; we can suggest that the acquisition of vocational and higher education (and, hence, the formation of human capital) in Ukraine is due not so much to its funding as to other factors such as internal motivation, incentives, regional features.

In the structure of expenditure on health care, the highest correlations of HCI to expenditure from the Social Insurance Fund (0.9819), private expenditure on health insurance funds $(-0.8660)$, and other nonstate expenditure (worldwide, -0.8660), the lowest correlation is to the private expenditure on voluntary insurance (0.5410) (Table 2).

Additional calculations of the relationship between HCI and health care funding by type of health care have shown strong correlations of HCI to inpatient costs, ancillary services for medical treatment, and the

Table 1

Correlation matrix between $\mathrm{HCI}$, education, and health expenditures

\begin{tabular}{|c|c|c|c|c|c|}
\hline Indicators & HCI & $\begin{array}{c}\text { Public expenditure } \\
\text { on education }\end{array}$ & $\begin{array}{c}\text { Private expenditures } \\
\text { on education }\end{array}$ & $\begin{array}{c}\text { Public expenditure } \\
\text { on health care }\end{array}$ & $\begin{array}{c}\text { Private expenditure } \\
\text { on health care }\end{array}$ \\
\hline HCI & 1 & & & & \\
\hline Public expenditure on education & 0.726158198 & 1 & & & \\
\hline Private expenditures on education & 0.598382302 & 0.9853747 & 1 & & \\
\hline Public expenditure on health care & 0.714461737 & 0.9998578 & 0.988107982 & 1 & \\
\hline Private expenditure on health care & 0.710346357 & 0.9997417 & 0.988992694 & 0.9999828 & 1 \\
\hline
\end{tabular}

Source: based on (Derzhavna sluzhba statystyky Ukrainy, 2020)

Table 2

Correlation matrix between HCI, expenditures on education and health

\begin{tabular}{|c|c|c|c|c|c|c|c|c|c|c|}
\hline & 它 & 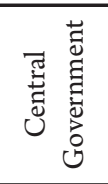 & 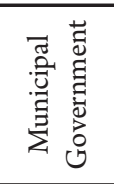 & 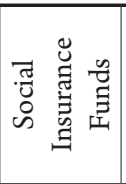 & 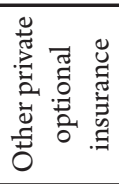 & 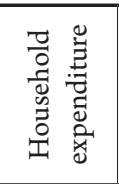 & 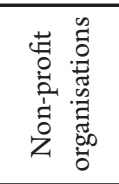 & 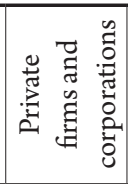 & 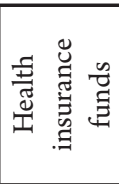 & 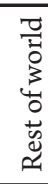 \\
\hline $\mathrm{HCI}$ & 1 & & & & & & & & & \\
\hline Central Govern-ment & 0.7023 & 1 & & & & & & & & \\
\hline Municipal Government & 0.7147 & 0.9998 & 1 & & & & & & & \\
\hline Social Insurance Funds & 0.9819 & 0.5554 & 0.5696 & 1 & & & & & & \\
\hline Other private optional insurance & 0.5410 & 0.9786 & 0.9748 & 0.37236 & 1 & & & & & \\
\hline Household expenditure & 0.7136 & 0.9998 & 0.9999 & 0.56844 & 0.97522 & 1 & & & & \\
\hline Non-profit organisations & 0 & 0.7118 & 0.6994 & -0.189 & 0.841 & 0.70047 & 1 & & & \\
\hline Private firms and corporations & 0.8170 & 0.9842 & 0.9872 & 0.69338 & 0.92694 & 0.98698 & 0.57656 & 1 & & \\
\hline Health insurance funds & -0.866 & -0.9642 & -0.9687 & -0.7559 & -0.8891 & -0.9683 & -0.5 & -0.9959 & 1 & \\
\hline Rest of world & 0.86603 & 0.9641 & 0.9686 & 0.75593 & 0.88905 & 0.9683 & 0.5 & 0.99587 & 1 & 1 \\
\hline
\end{tabular}

Source: based on (Derzhavna sluzhba statystyky Ukrainy, 2020) 
provision of medical supplies to outpatients. Additional calculations of the relationship between $\mathrm{HCI}$ and health care funding by type of health care have shown strong correlations of HCI to inpatient costs, ancillary services for medical treatment, and the provision of medical supplies to outpatients.

Instead, the analysis between $\mathrm{HCI}$ and provider costs showed strong correlations of $\mathrm{HCI}$ to the general health management and health insurance costs; in our opinion, such results of the analysis show that the reproduction of human capital is not due to the actual medical services, but due to health policy and health insurance. Thus, summarizing all the above facts, we can state that in the financing of education in Ukraine the leading role is played by public sector funds; expenditure of households predominate in the expenditure structure of the private sector. Regarding health care, expenditures on general health care and health insurance have had a positive impact on HCI 2020, which indicates the need to introduce compulsory health insurance as a separate type of insurance or as part of the human capital development fund in Ukraine.

\section{Relationship between the cost of human capital development and wages}

Given the motivational function, let us check whether wages are an indicator of the effectiveness of financing human capital development, using regression and correlation analysis of the dependence of average wages of full-time employees (y) on the amount of funding for education and health care by funding sources (Table 3): public expenditure of the central government on education $\left(\mathrm{x}_{1}\right)$ and health care $\left(\mathrm{x}_{2}\right)$, local budget expenditures on education $\left(\mathrm{x}_{3}\right)$ and health care $\left(\mathrm{x}_{4}\right)$, private expenditures of houdeholds on education $\left(\mathrm{x}_{5}\right)$ and health care $\left(\mathrm{x}_{6}\right)$, expenditure of private firms and corporations on education $\left(\mathrm{x}_{7}\right)$, expenditure of Social Insurance Funds on health care $\left(\mathrm{x}_{8}\right)$, other nongovernment expenditures on health care $\left(\mathrm{x}_{9}\right)$.

The results of the analysis have shown that all sources of human capital funding have a significant impact on the average salary. At the same time, the connection between all indicators, except for the financing of health care at the expense of health insurance funds, is direct. The initial regression model, which takes into account the impact of all sources of funding on the average salary, is too cumbersome and inadequate, and therefore it has been simplified by consistently eliminating the least statistically significant factors, especially in public funding, which is aimed, inter alia, to cover expenditure on wages for education and health workers. The result is a model that explains $99 \%$ of the variation of the independent variable and is adequate by Fisher's criterion and with statistically significant variables by Student's criterion.

The average coefficients of elasticity of the factors of the resulting model are, respectively:

$$
\begin{aligned}
& E_{x_{3}}=31,12 * \frac{\bar{x}_{3}}{\bar{y}}=0,577, \\
& E_{x_{6}}=11,56 * \frac{\bar{x}_{6}}{\bar{y}}=0,189, \\
& E_{x_{9}}=416,87 * \frac{\bar{x}_{9}}{\bar{y}}=0,409
\end{aligned}
$$

The variable $\mathrm{x}_{3}$ has the greatest influence on the resulting factor $(\mathrm{y})$, the smallest $-\mathrm{x}_{6}$. Thus, the formation of human capital is influenced by various sources of funding. In particular, the size of the average wage is affected by the expenditure of local budgets on education, private expenditure of households and other

Table 3

\begin{tabular}{|c|c|c|c|c|c|c|}
\hline \multirow[b]{2}{*}{ 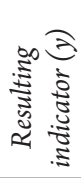 } & \multirow[b]{2}{*}{$\begin{array}{l}\text { Number of } \\
\text { factors }\end{array}$} & \multirow[b]{2}{*}{ Equation } & \multicolumn{4}{|c|}{ Parameters } \\
\hline & & & $\begin{array}{l}\text { Correlation } \\
\text { coefficient, } \mathrm{R}\end{array}$ & $\begin{array}{c}\text { Determination } \\
\text { coefficient, } \\
\mathrm{R}^{2}\end{array}$ & $\begin{array}{c}\text { F fact, } \\
\text { Fcrit }=2,7963 \\
(p=0,95)\end{array}$ & $\begin{array}{c}\mathrm{t} \text {-fact, } \\
t \text {-crit }=3,1824\end{array}$ \\
\hline 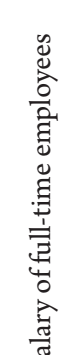 & 9 & $\begin{array}{c}\mathrm{y}=51.76 \mathrm{x}_{1}+230.54 \mathrm{x}_{2}+14.03 \mathrm{x}_{3}- \\
19.92 \mathrm{x}_{4}+73.82 \mathrm{x}_{5}+8.16 \mathrm{x}_{6}-2537.28 \mathrm{x}_{7^{-}} \\
29.62 \mathrm{x}_{8}+318.34 \mathrm{x}_{9}-1710.82\end{array}$ & 0.9999 & 0.9999 & 2947.24 & $\begin{array}{l}\mathrm{x}_{1}=1.78 \\
\mathrm{x}_{2}=1.95 \\
\mathrm{x}_{3}=1.72 \\
\mathrm{x}_{4}=1.37 \\
\mathrm{x}_{5}=1.89 \\
\mathrm{x}_{6}=2.35 \\
\mathrm{x}_{7}=1.88 \\
\mathrm{x}_{8}=1.93 \\
\mathrm{x}_{9}=3.98\end{array}$ \\
\hline 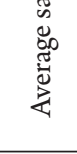 & 3 & $y=31.13 x_{3}+11.56 x_{6}+416.87 x_{9}-659.85$ & 0.9998 & 0.9996 & $\begin{aligned} \mathrm{F} f a c t & =7282.66 \\
\text { Fcrit } & =3.4903 \\
(p & =0.95)\end{aligned}$ & $\begin{array}{c}t \text {-crit }=2.2622 \\
\mathrm{x}_{3}=15.13 \\
\mathrm{x}_{6}=5.77 \\
\mathrm{x}_{9}=11.31\end{array}$ \\
\hline
\end{tabular}

Economic and mathematical models of the impact of changes in the volume of human capital financing on the average salary of full-time employees

Source: based on (Derzhavna sluzhba statystyky Ukrainy, 2020) 
non-government expenditures on health care. Thus, an increase in local budget expenditure on education by $1 \%\left(\right.$ variable $\mathrm{x}_{3}$ ) may lead to an increase in the average salary of full-time employees by $0.577 \%$; an increase in private expenditure of households on health by $1 \%$ may lead to an increase in the average wage by $0.189 \%$, and with an increase in the share of other non-government expenditure on health care by $1 \%$, the average wage will increase by $0.409 \%$.

Thus, it is analytically proven that wages are the main and generalizing indicator of the effectiveness of expenditures on education and health care. Other indicators (employment of graduates of educational institutions, hours worked, morbidity) due to the lack of correlation and causation cannot characterize the effectiveness of education and health care financing comprehensively and reliably.

\section{Financial instruments for human capital development}

Implementation of structural reforms and systemic transformations in the context of achieving sustainable development of Ukraine requires high-quality human capital, the development and use of which involves the financing of education and lifelong learning. Given the interdependence of wages (therefore, opportunities to reduce poverty, improve the quality of life of citizens and achieve sustainable development goals) and expenditures on education, training and health care, as well as a number of constraints (such as income, change of types of work) and threats (military conflict, pandemic, migration of human resources), it is advisable to implement structural reforms and systemic transformations aimed at optimizing the financing of education, training and health care in Ukraine.

The main financial instruments that need to be used for making changes in education and health are:

1) optimization of public funding of human capital, taking into account the results of research by reputable international organizations and a reliable evidence base (The Human Capital Index 2020 Update, 2020);

2) creation of fiscal space for financing the development of human capital by involving the whole society, identifying intersectoral synergies, and implementing cost-effective state interventions in the processes of human capital reproduction;

3) creation of regional funds for financing human capital development and establishment of a tax on human capital development in the amount of $1-5 \%$;

4) creation of strategic alliances and partnerships involving financial and credit institutions; participation of educational institutions in joint projects with the corporate sector;

5) stimulation of the corporate sector to finance human capital development and promote its accumulation (Olievska, 2019);
6) supporting the demand for education and health care from households by means of targeted cash transfers and job retention (The Human Capital Index 2020 Update, 2020).

As a result, it is necessary to ensure stable funding for education and health care, regardless of existing and new challenges, as the development and accumulation of human capital is a national priority in Ukraine (as in the other lower-middle-income countries).

However, the effectiveness and efficiency of the above tools depend on: firstly, the modernization of preschool and complete general secondary education, vocational, and higher education, bringing educational standards to the needs of social development and the best world standards; secondly, the availability of efficient jobs in Ukraine; thirdly, ensuring equal opportunities for men and women; fourthly, ensuring human rights to health care, including the promotion of healthy lifestyle, disease prevention, early diagnosis, quality comprehensive treatment, rehabilitation from the first days of the disease, palliative care, transplantation development, adequate medical care, implementing standards of affordable and quality medical services, etc. (Pro Stratehiiu natsionalnoi bezpeky Ukrainy, 2020). In our opinion, the inclusion of such tasks in the National Security Strategy is the right, but not the only sufficient step towards the development of human capital in Ukraine in the near future. Execution of tasks and achievement of goals depends on the close interaction of financial and non-financial instruments.

\section{Conclusions}

Education and health care systems in Ukraine have both strengths (years of study, level of education of the population) and weaknesses (limited access to educational and medical services, quality of services, the amount of public expenditures on education, low use of accumulated human capital), which makes them vulnerable to new challenges and inevitable changes.

Based on the study, the following conclusions can be drawn: firstly, human capital development depends on the financial capabilities and organizational decisions of the governments; high-income countries have higher human capital development rates; secondly, Ukraine belongs to the lower-middle-income countries and does not fully use its domestic potential for human capital development; thirdly, the study of the dynamics and structure of expenditures on education and health care shows a high level of public expenditure on education and almost no expenditure of households; in the structure of distribution of health care expenditure it is established that the expenditures are carried out proportionally at the expense of both government and non-government sectors; fourthly, it is analytically proven that the cost of human capital development affects the size of wages. 
The main steps required for changes in the financing of human capital development are as follows: optimization of public funding of human capital; creation of fiscal space; creation of regional funds for financing human capital development; creation of strategic alliances and partnerships; stimulation of the corporate sector; supporting the demand for education and health care from households. Carrying out reforms in education and health care in lower-middle-income countries requires: modernization of education and health care systems; elimination of gender inequalities; creation of effective jobs with a reasonable level of wages.

\section{References:}

Avitabile, Ciro; D’Souza, Ritika; Gatti, Roberta V.; Chapman, Emily Weedon (2020). Insights from Disaggregating the Human Capital Index (English). Washington, D.C. : World Bank Group. Available at: http://documents. worldbank.org/curated/en/306651578290912072/Insights-from-Disaggregating-the-Human-Capital-Index (accessed 20 January 2021).

Becker Gary (1993) [1964]. Human capital: a theoretical and empirical analysis, with special reference to education (3rd ed.). Chicago: The University of Chicago Press.

Christian Dustmann, Costas Meghir, Wages, Experience and Seniority, The Review of Economic Studies, vol. 72, issue 1, January 2005, pp. 77-108.

Derzhavna sluzhba statystyky Ukrainy (2020). Available at: http://www.ukrstat.gov.ua/ (accessed 9 January 2021). Herrendorf, Berthold, and Todd Schoellman (2018). "Wages, Human Capital, and Barriers to Structural Transformation." American Economic Journal: Macroeconomics, vol. 10(2), pp. 1-23.

Mincer Jacob. "Investment in Human Capital and Personal Income Distribution,” Journal of Political Economy, August 1958.

New World Bank country classifications by income level: 2020-2021. Available at: https://blogs.worldbank.org/ opendata/new-world-bank-country-classifications-income-level-2020-2021 (accessed 20 January 2021).

Olievska, M. (2019). Liudskyi capital u konteksti dosiahnennia tsilei staloho rozvytku. Finansy Ukrainy, vol. 12, pp. 32-43.

Pro Stratehiiu natsionalnoi bezpeky Ukrainy: Available at: https://www.president.gov.ua/documents/ 3922020-35037 (accessed 17 January 2021).

World Bank (2020). "COVID-19 and Human Capital" Europe and Central Asia Economic Update (Fall), Washington, DC: World Bank. doi: 10.1596/978-1-4648-1643-7. License: Creative Commons Attribution CC BY 3.0 IGO (accessed 17 January 2021).

World Bank (2020). The Human Capital Index 2020 Update : Human Capital in the Time of COVID-19. World Bank, Washington, DC. (C) World Bank. Available at: https://openknowledge.worldbank.org/handle/ 10986/34432 (accessed 9 January 2021).

United Nations (2015, September 25). Transforming our world: the 2030 agenda for sustainable development (n.d.). Available at: http://www.un.org/ga/search/view_doc.asp?symbol=A/70/L.1\&Lang=E 